\title{
STRATIGRAPHIC ASPECTS AND FACIES DESCRIPTION OF MIRANDIBA BASIN, NORTHEAST, BRASIL
}

\author{
Laís Cristina Leite Pereira ${ }^{1}$ \\ Luis Henrique Aguiar de Araújo ${ }^{1}$ \\ Gisely Maria da Silva ${ }^{1}$ \\ 10.18190/1980-8208/estudosgeologicos.v28n2p108-125 \\ Mário Ferreira de Lima Filho ${ }^{2}$ \\ ${ }^{1}$ Programa de Pós-graduação em Geociências, UFPE, (leite_lais@ @otmail.com), \\ (luishenrique-@hotmail.com), (giselymaria.silva@gmail.com). \\ ${ }^{2}$ Departamento de Geologia e Pós-graduação em Geociências, UFPE, (mflf@ufpe.br).
}

\begin{abstract}
Mirandiba Basin, located in the central portion of the State of Pernambuco, represents one of the Northeast Brazilian intracontinental rift basins. Considering the lack of geological studies in this area, this research aims to document and describe the main sedimentological and faciological aspects observed in Mirandiba Basin. The methodology involved the observation of Google Earth's images, and the analysis of the Digital Elevation Model (DEM), derived from SRTM (Shuttle Radar Topography Mission), in order to provide a better view of the area and to promote the selection of the best outcrops. Four sedimentary formations were identified in this study. The Tacaratu Formation (Siluro-Devonian) represents the oldest and most abundant sediments of the basin and it is essentially composed of sandstone dominated facies. As main characteristics, the basin shows the presence of deformation bands, mainly at its border, and the common presence of conglomeratic levels, as well. The Inajá Formation, located stratigraphically above Tacaratu Formation, is marked by sandstone facies (composed of reddish sandstones, eventually containing small limonite nodules) and by a siltstone facies. The Aliança Formation consists of two facies: (i) red to brown shales, representing the most abundant facies and (ii) calciferous siltstone (which contains ostracods), usually interbedded between layers of the anterior facies. The Sergi Formation, which presents the smallest extent, is dominated by the presence of sandstone facies; however, conglomeratic and siltstone facies are also observed. Four facies associations (S1, S2, S3 and F1) were described to characterize two main depositional systems in Mirandiba Basin. Associations S1, S2 and S3 characterize a typical fluvial braided system associated to the Tacaratu, Inajá and Sergi formations, whereas F1 association describes a lacustrine environment in the Aliança Formation.
\end{abstract}

Keywords: Mirandiba Basin, Northeast Brazilian Intracontinental Rift Basins, stratigraphy, facies association, Digital Elevation Model.

\section{RESUMO}

A Bacia Mirandiba, localizada na porção central do estado de Pernambuco, representa uma das bacias interiores do Nordeste. Considerando a falta de estudos em geologia nesta área, esta pesquisa tem como objetivo documentar e descrever os principais aspectos sedimentológicos e faciológicos observados na Bacia de Mirandiba. A metodologia envolveu além da observação de imagens do Google Earth, a análise do Modelo Digital de Elevação (DEM), derivado do SRTM (Shuttle Radar Topography Mission), ambas com intuito de proporcionar uma melhor visualização da área e seleção dos melhores afloramentos. Quatro formações sedimentares foram identificadas neste estudo. A 
Formação Tacaratu (Siluro-Devoniano) representa os sedimentos mais abundantes e antigos da bacia e é composta por fácies essencialmente arenosas. Como características principais estão a presença de bandas de deformação principalmente na borda da bacia, além da comum presença de níveis conglomeráticos. A Formação Inajá, localizada estratigraficamente acima da Formação Tacaratu, é marcada por fácies arenosas (compostas por arenitos vermelhos contendo, por vezes, nódulos limoníticos) e por uma fácies siltítica. A Formação Aliança é composta por duas facies: (i) folhelhos vermelhos a marrons, representando a fácies mais abundante e (ii) arenitos calcíferos, geralmente intercalados entre camadas da fácies anterior. A Formação Sergi, a qual apresenta a menor extensão, é dominantemente marcada por presença de fácies arenosa, no entanto, também são observadas fácies conglomerática e siltosa. Quatro associação de fácies (S1, S2, S3 and F1) foram descritas para caracterizar os dois principais sistemas deposicionais da Bacia Mirandiba. A associação de fácies S1, S2 e S3 caracterizam um sistema fluvial entrelaçado associado as formações Tacaratu, Inajá e Sergi, enquanto a associação F1 descreve um sistema deposicional lacustre caracterizado na Formação Aliança.

Palavras-chave: Bacia Mirandiba, Bacias interiores do Nordeste, estratigrafia, associação de fácies, Modelo Digital de Elevação.

\section{INTRODUCTION}

sedimentological facies observed in

The evolution of northeast Brazilian intracontinental rift basins, including their tectonic, structural and sedimentary aspects, have been addressed in several studies since the 1970's (e.g. Ponte, 1971; Conceição et al., 1988; Matos, 1992; Matos, 1999). These studies treated those basins in a regional matter and did not discuss properly their individualities, except for the Araripe Basin. Probably, this could be due to their size and variety of stratigraphic record. Basins as Mirandiba, Betânia, and São José do Belmonte cover regions of $140 \mathrm{~km}^{2}, 280$ $\mathrm{km}^{2}$ (Aguiar et al., 2010) and $750 \mathrm{~km}^{2}$ (Costa et al., 2006), respectively. On the other hand, the Araripe Basin comprises an area of $9.000 \mathrm{~km}^{2}$.

In order to minimize this issue, a geological mapping was performed through the limits of Mirandiba Basin. It involved the description of its main sedimentological and stratigraphic aspects. Thus, the aims of this paper are: (1) to document a set of sedimentary formations recognized on the field, and (2) to describe the principal

\section{GEOLOGICAL SETTING}

Mirandiba Basin represents one of the Brazilian intracontinental rift basins. It is located in the Central Domain of Borborema Province and it is placed, specifically, in Alto Pajeú Terrain, which is limited by the lineaments Patos to the north and Pernambuco to the south (Fig. 1) (Medeiros, 2004). The basement rocks are represented by Precambrian metamorphic (gneiss, migmatite, schist, quartzite) and igneous rocks (granite and syenite) (Silva Jr., 1997). The main regional structures are E-W and NE-SW transcurrent shear zones. These megashears have their genesis related to the evolution of the Brasiliano-PanAfrican Orogeny $(0.6-0.58 \mathrm{Ga})$ (Vauchez et al, 1995). According to Matos (1999), this complex network of regional shear zones controls the crustal heterogeneities around the Central domain. It only discussed about early-rift and post-rift stage.

In general, when discussing about the evolution intracontinental rift basins of Brazil, Mattos (1992) suggests three 
different stages known as Sin-rift I, II and III based on structural style, rift dynamics, and stratigraphic variations

The first one occurred in the Late Jurassic and records the initial phase of the rifting process marked by a crustal extensional deformation with deposition of clastic sediments in a wide and shallow basin. The second occurred in early Cretaceous (Neocomian age) and is characterized by the presence of faulted strata (syndepositional conditions) deposited in the intracontinental rift basins. The final stage known as Sin-rift III (Barremian age) represents the climax stage of the rifting process. Then, the extensional process started to be focused along the South Atlantic continental margin

In a similar way to other intracontinental basins of the Northeast of Brazil, the development of Mirandiba Basin comprises two main evolutionary phases (Leite et al., 2000; Silva Jr., 1997). The first one consists of a thermal subsidence (syneclisis) during Paleozoic. The other is related to a rifting phase, which consists of a sequence of tectonic events related to the fragmentation of Gondwana Paleocontinent and further South Atlantic Ocean opening, during Neojurassic and Cretaceous (Matos, 1992; Matos, 1999).

The Mirandiba Basin records two tectonosequences. The first sequence, termed as Beta sequence, represents the earliest depositional cycle reported in Brazilian intracratonic basins. It corresponds to a complete transgressiveregressive cycle occurred during the Silurian-Devonian period with a depositional system being formed by continental and shallow marine environments (Soares et al., 1978; Ponte and Ponte Filho, 1996; Rocha \& Leite, 1999). The second one is termed pre-rift sequence representing the precursor stage of the rifting process. Some authors argue that it represents the early stage of the rifting process. For these authors the lithosphere was already stretching, however, faults and other main structures were still not generated at this point (Matos, 1999). Furthermore, it comprises an exclusive continental depositional cycle formed by Jurassic lacustrine and fluvial-eolian deposits (Rocha \& Leite., 1999; Ponte \& Ponte Filho., 1996).

Due to similarities, in terms of lithostratigraphic record, and spatial proximity, some authors (e.g. Braun, 1966; Aguiar, et al., 2010; Brasilino et al., 2014) correlated Mirandiba Basin stratigraphic formations to those present in Jatobá Basin. Following these assumptions, as well as the fact that Mirandiba Basin does not have its own stratigraphic chart, we also used Jatobá Basin lithostratigraphic terminology to assign different formations in Mirandiba Basin. 


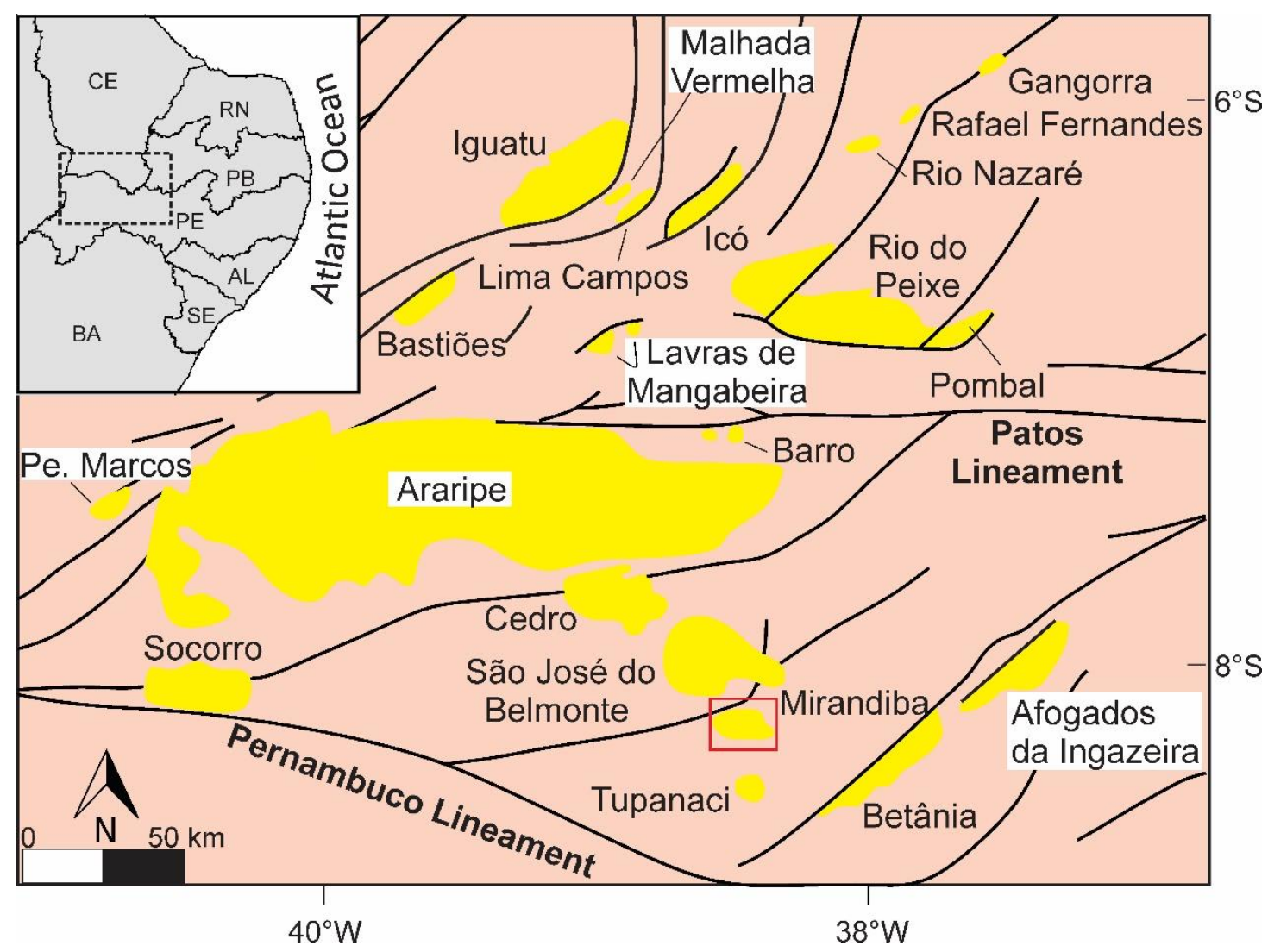

Figure 1: Simplified geological map showing the Northeast Brazilian intracontinental rift basins. The study area, Miranbiba Basin, is highlighted in the red square (modified from Ponte, 1991).

\section{MATERIAL AND METHODS}

The analysis of Mirandiba Basin sedimentary and faciologic characteristics was grounded by a 1:50.000 scale geological mapping, in which approximately 80 outcrops were studied during three fieldwork stages. DEM (Digital Elevation Model) images (30 $\mathrm{m}$ resolution) derived from SRTM (Shuttle Radar Topography Mission) provided by the Brazilian Geomorphometric Data Bank (TOPODATA), were used in order to achieve a regional topographic visualization (Fig. 2). In addition, Google Earth images were used to identify the best land exposures.
Facies analysis presented here was based on the classification scheme of Miall (1996).

\section{RESULTS}

Four different sedimentary formations were identified in this study: Tacaratu, Inajá, Aliança, and Sergi (Fig. 3 ). The first two are Paleozoic. Tacaratu Formation date from the Silurian/Devonian period (Barbosa, 1964), while Inajá Formation, from the Devonian period (Barreto, 1968; Pereira et al., 2012). The younger formations (Aliança and Sergi) are Mesozoic and date from Upper Jurassic (Leite et al., 2000, Silva et al., 2017). 


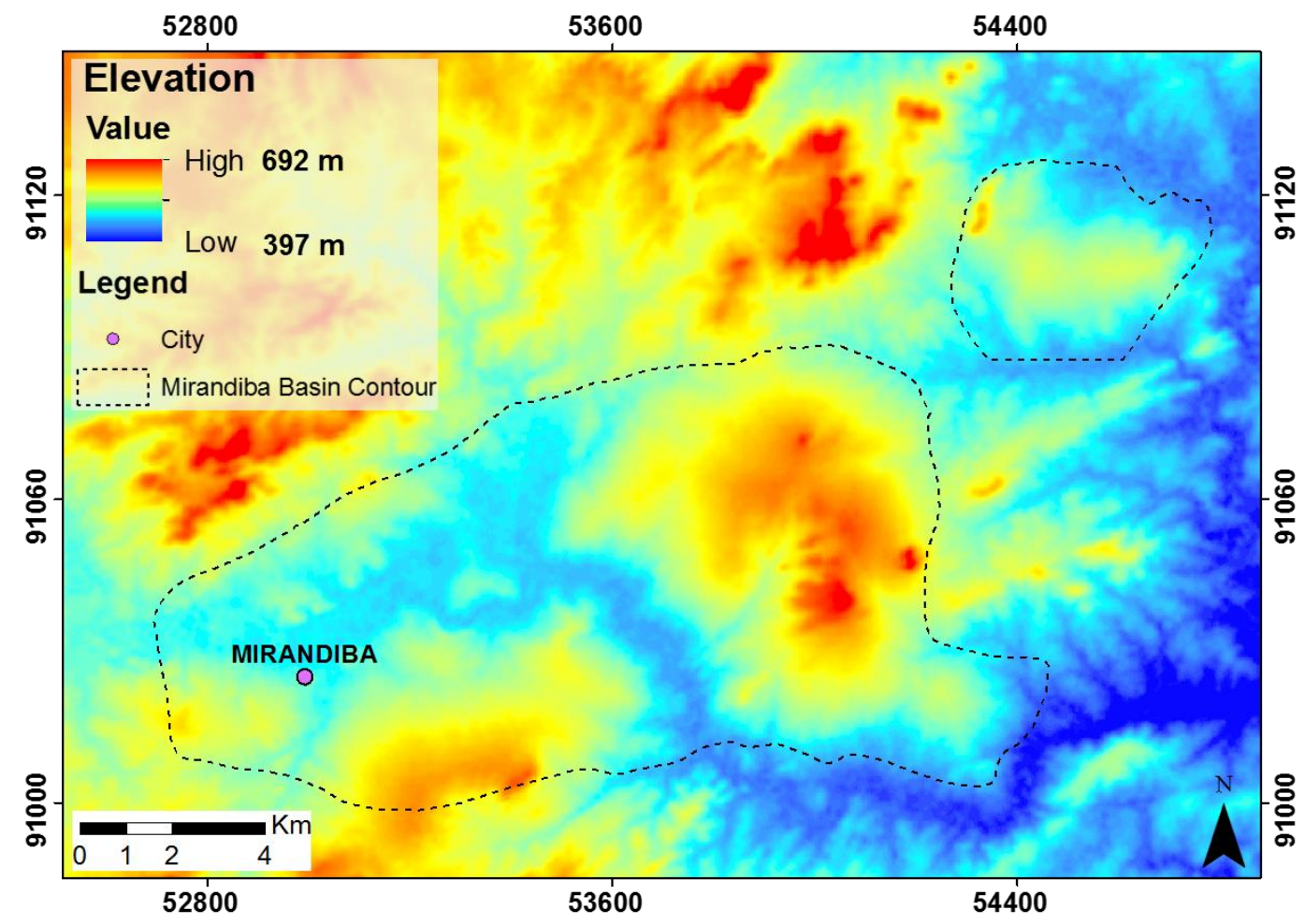

Figure 2: DEM image displaying the topographic variation in the study area. The dashed region represents Mirandiba Basin contour.

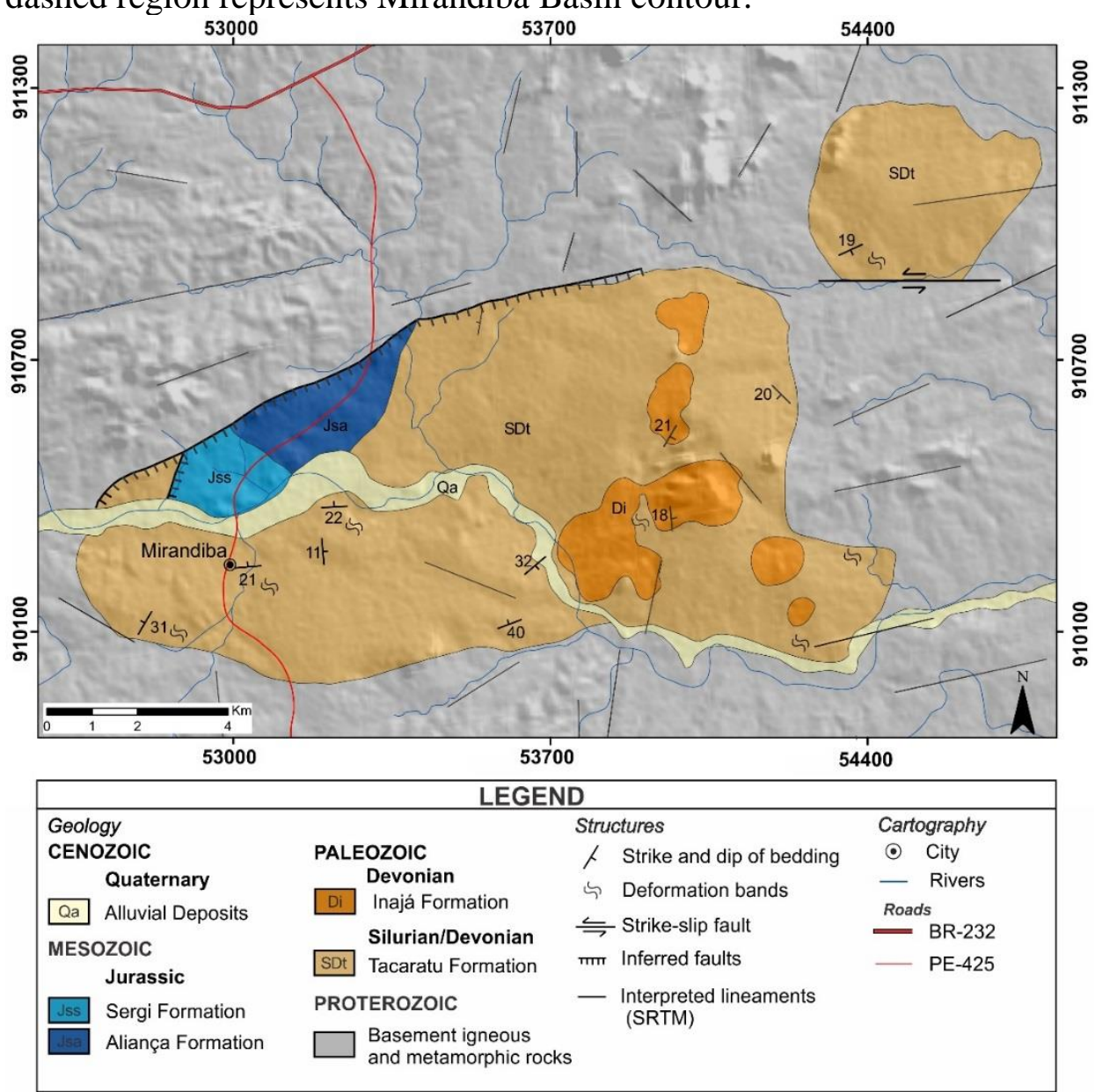

Figure 3: Simplified geologic map of Mirandiba Basin superimposed over the DEM image (directionally filtered in the $135 \mathrm{Az}$ orientation). 


\section{Tacaratu Formation}

The Tacaratu Formation represents Mirandiba Basin wider formation, covering an area of approximately 100 $\mathrm{km}^{2}$. Its outcrops generally present 0.3 to 1.5 meters in height, but some residual inselbergs reaching up to 7 meters are observed (Fig. 4A).

The formation is composed by fine- to very coarse-grained (predominantly coarse), pale yellow to white sandstones showing, locally, conglomeratic levels (Fig. 4B), and pebbles spread in its matrix. The mineralogy is represented essentially by quartz ( $80-90 \%)$, but feldspar and mica crystals (e.g. muscovite) are usually identified (Fig. 4C). Overall, these sandstones are moderately sorted, structureless, highly consolidated and show subrounded grains. However, those characteristics may vary among the different facies recognized.

The sandstone layers show cross and horizontal stratification (Fig. 4D) and inverse grading, but most are structureless. The strata show tabular geometry, dipping at low to moderate angles $\left(10^{\circ}-40^{\circ}\right)$ to $\mathrm{NW}$ and NE. Deformation bands are typically observed close to the margin of the basin.

A nonconformity was identified in SW part of the basin. It is defined by the contact of Tacaratu Formation and the gneissic-migmatitic Serra Talhada Complex (Fig. 4E).

\section{FACIES DESCRIPTIONS}

Three different facies were recognized in Tacaratu Formation studied outcrops. All of them are sandstone dominated.

\section{Sm: Massive sandstone}

This facies is composed of fine- to very coarse-grained sandstone. The grains are moderately sorted and subrounded. Occurrences in which the grain size vary from coarse to very coarse is common to observe a considerable amount of feldspar (up to $20 \%$ ) and muscovite ( 2\%). In some cases, this sandstone has a pebbly admixture. The sets' thickness varies from 0.28 to $1.3 \mathrm{~m}$.

\section{Sh: Horizontally stratified sandstone}

This facies consists of horizontally stratified, medium- to coarse-grained sandstone, with rounded to subrounded grains. The set's thickness reaches up to $80 \mathrm{~cm}$.

\section{Sp: Cross-stratified sandstone}

This facies is represented by medium- to coarse-grained, crossstratified sandstone. Pebbles, usually of size varying from $0.5-5 \mathrm{~cm}$, are commonly present in the base of sets (pebble lag), or between cross-strata (Figure 5). The sets' thickness varies from 0.2 to $2 \mathrm{~m}$.

Table 1: Facies recognized at Tacaratu Formation in Mirandiba Basin, following the approach of Miall (1977) and Miall (1996).

\begin{tabular}{|c|c|c|}
\hline Facies & Structures & Interpretation \\
\hline Sm & Structureless (massive) & $\begin{array}{c}\text { Bioturbated sand, or deposition by suspension } \\
\text { fallout. }\end{array}$ \\
\hline Sh & Horizontal stratification & Streams high speed flat bed. \\
\hline Sp & Cross-stratification & $\begin{array}{l}\text { Unidirectional migration of subaqueous two- } \\
\text { dimensional dunes. }\end{array}$ \\
\hline
\end{tabular}




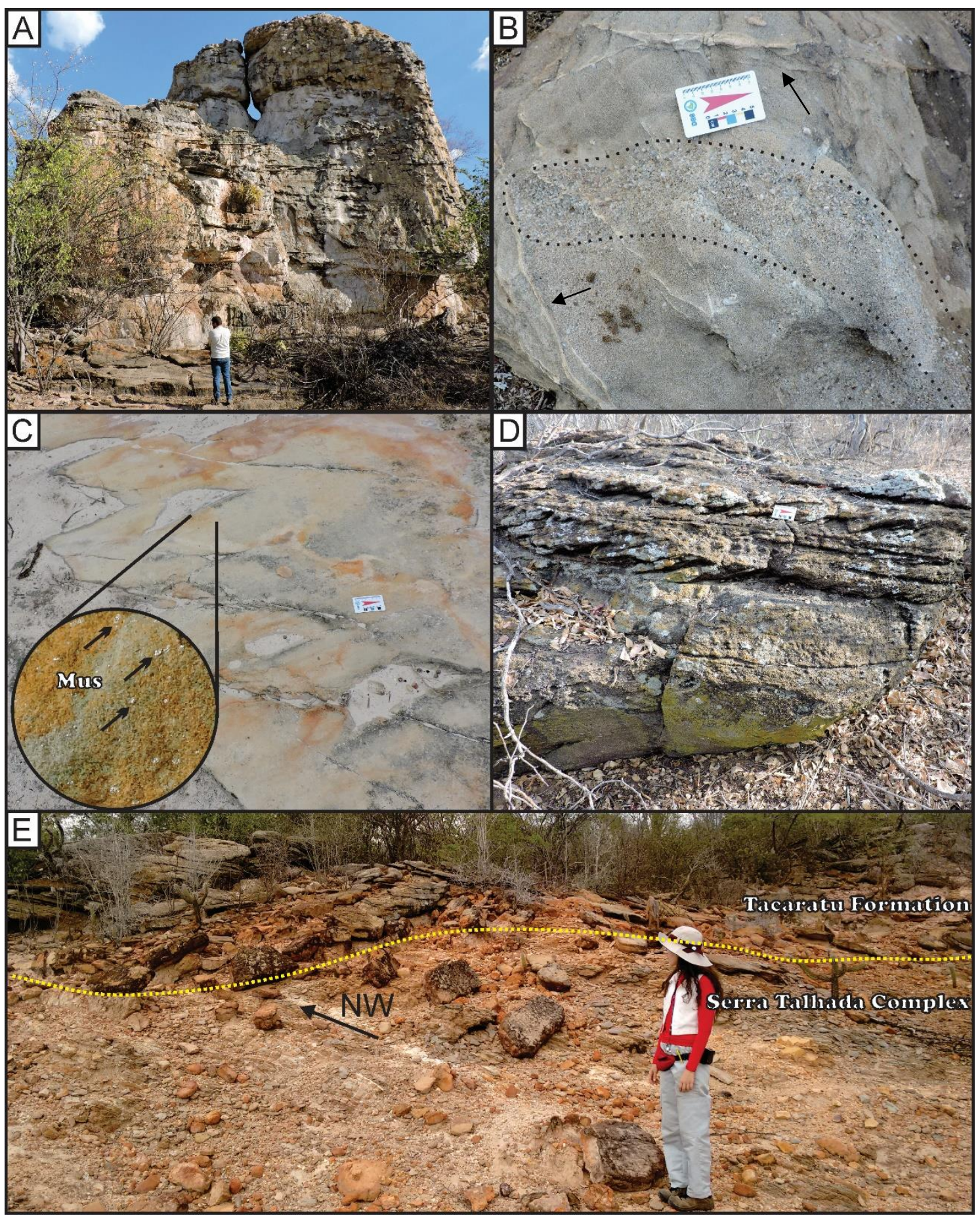

Figure 4: (A) Overview of a residual inselberg (approximately $7 \mathrm{~m} \mathrm{high}$ ) observed in Tacaratu Formation. (B) Coarse-grained sandstone showing conglomeratic level, indicated by dashed line, and deformation bands (see arrow). (C) Overview of mediumgrained, pale yellow sandstone. In detail, the collected sample showing muscovite crystals. (D) Outcrop of Tacaratu Formation showing massive (on the base) and crossstratified (on the top) layers. (E) Nonconformity defined by the contact between Tacaratu Formation sandstone and Serra Talhada Complex gneiss (198Az/26\%108Az). 


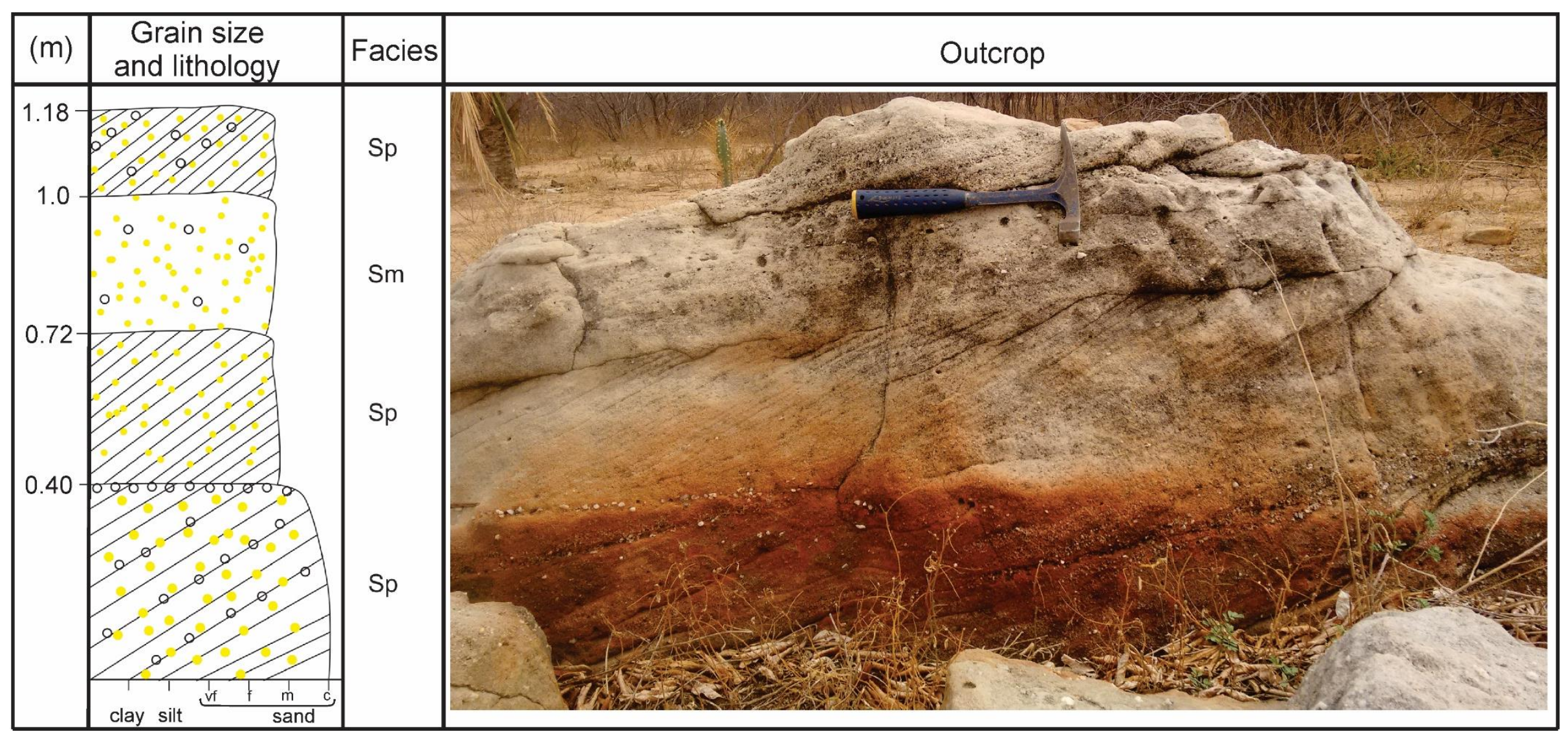

Figure 5: Stratigraphic column of Tacaratu Formation outcrop showing a fining upwards grain size trend. The bottom layer is a coarse-grained sandstone containing pebbles between different cross-strata. Its contact with the following layer is marked by pebble lag ( $1 \mathrm{~cm}$ thick). The subsequent layers (in upward direction) show (i) cross-stratification, (ii) massive texture (with some pebbly admixture), and (iii) cross-stratification. 


\section{Inajá Formation}

The outcrops of Inajá Formation are located in the eastern portion of the basin, stratigraphically above the Tacaratu Formation and cover an area of approximately $9 \mathrm{~km}^{2}$. The formation is observed in the highest parts of the basin (reaching up to $590 \mathrm{~m}$ of elevation) and shows a plateau morphology (Fig. 6A).

Inajá Formation is composed by reddish, fine- to coarse-grained, highly consolidated sandstone (predominantly fine-grained) and yellow to creamcolored siltstone. The sandstone grains are moderated sorted and vary from rounded to sub-angular. In situ spheroidal limonitic nodules $(1-15 \mathrm{~cm})$ occur dispersed in the sandstone. Locally, iron concretions with $80 \mathrm{~cm}$ to $1 \mathrm{~m}$ diameter were observed (Fig. 6B).

The sandstone layers are tabular and, in some occurrences, show shallow dip angle $\left(\sim 15^{\circ}\right)$ to NW or NE. The main sedimentary structures identified in Inajá Formation were horizontal stratification, cross-stratification (Fig. 6C) and ripple marks (Fig. 6D).

\section{FACIES DESCRIPTIONS}

\section{Sm: Massive Sandstone}

Fine-grained, well-sorted sandstone, with subrounded to rounded grains. Locally show spheroidal limonitic nodules disperse randomly in the matrix. In some occurrences, the content of muscovite and feldspar is up to $10 \%$.

\section{Sh: Horizontally stratified sandstone}

Medium- to coarse-grained sandstone, moderately sorted, with subrounded grains. Present horizontal stratification.

\section{Sp: Cross-stratified sandstone}

Fine- to coarse-grained sandstone, moderately sorted, showing subrounded grains. Locally, show, as Sm facies, limonitic nodules disperse in the matrix. Individual beds reach up to $35 \mathrm{~cm}$ (Fig. 6C).

\section{Sr: Rippled sandstone}

This facies consists of fine-grained sandstone, showing ripple marks (Fig. 6D).

\section{Fsm: Massive siltstone}

Only one occurrence of this facies was observed in the field. The layer exposed is about two meters thick and is stratigraphically underneath by sandstone layers (specifically facies Sm and Sp). The contact between this facies and the Facies $\mathrm{Sr}$ is abrupt, marking an unconformity. The facies is composed of yellow to cream-colored siltstone lacking sedimentary structures (Fig. 6E). 
Table 2: Facies recognized at Inajá Formation in Mirandiba Basin following the approach of Miall (1977) and Miall (1996).

\begin{tabular}{|c|c|c|}
\hline Facies & Structures & Interpretation \\
\hline Sm & Structureless (massive) & $\begin{array}{l}\text { Bioturbated sand, or deposition by suspension } \\
\text { fallout. }\end{array}$ \\
\hline Sh & Horizontal stratification & Streams high speed flat bed. \\
\hline Sp & Cross-stratification & $\begin{array}{l}\text { Unidirectional migration of subaqueous two- } \\
\text { dimensional dunes. }\end{array}$ \\
\hline $\mathrm{Sr}$ & Ripple marks & Ripples (lower flow regime). \\
\hline Fm & Structureless (massive) & Suspension load fall-out of mud bioturbated. \\
\hline
\end{tabular}

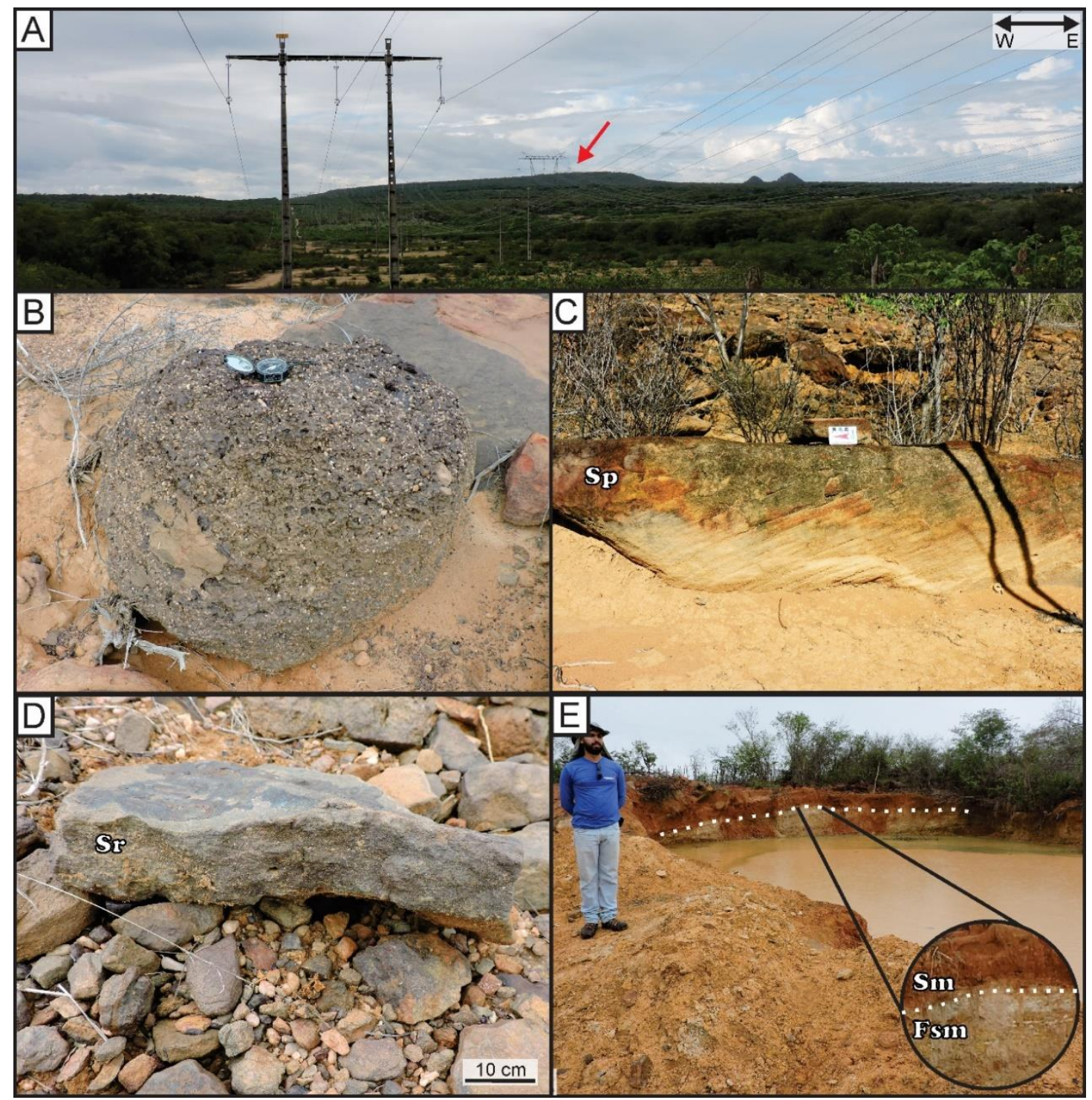

Figure 6: (A) Overview of plateau morphology exhibited by Inajá Formation rocks. (B) Outcrop showing 1 meter diameter iron concretion. (C) Bed approximately $35 \mathrm{~cm}$ thick, showing planar cross-stratification (Sp facies). (D) Ripple mark in fine-grained sandstone (Sc facies). (E) Abrupt contact between facies Fsm and Sm, which is easily noticed by differences in color and lithology: yellow to cream-colored siltstone and reddish sandstone, respectively. 


\section{Aliança Formation}

Aliança Formation consists of a discontinuous series of outcrops, located in the midwest part of Mirandiba Basin, covering an area of approximately $6 \mathrm{~km}^{2}$. Two types of lithologies are recognized in its extension: 1 - red to brown shale, characterizing the most abundant sort of rock in this formation; and interbedded with the former, discontinuous thin layers of 2 - calciferous sandstone (Fig. 7A, B). As reported by Silva et al. (2017), the calciferous sandstone contains non-marine ostracods, which are attributed to the genus Theriosynoecum (Fig. 8) and Alicenula (Fig. 9).

\subsubsection{Facies Descriptions}

Fm: massive mudstone and siltstone (shale)

Red to brown mudstone and shale (non-fossiliferous layer) (Fig. 7B).

Fsm: massive siltstone

Well sorted, fine-grained calciferous siltstone, showing green to gray colors (Fig. 7B). Ostracod shells constitute the grains, essentially (Fig. 7C).

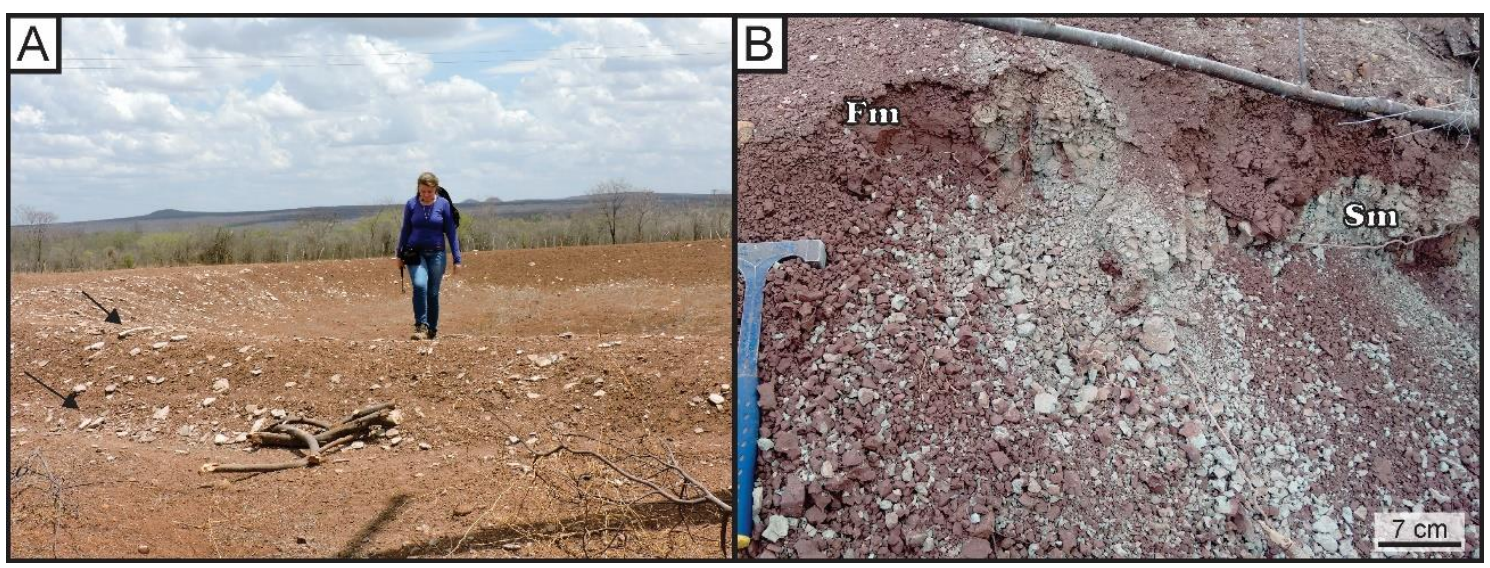

Figure 7: (A) Overview of Aliança Formation outcrop. Black arrows indicate fragments of calciferous sandstone (in gray color) (Sm facies), dispersed in brown shale (Fsm facies). (B) Detail showing the contact between a discontinuous thin layer of calciferous sandstone $(\mathrm{Sm})$ interbedded in reddish shale $(\mathrm{Fm})$. 


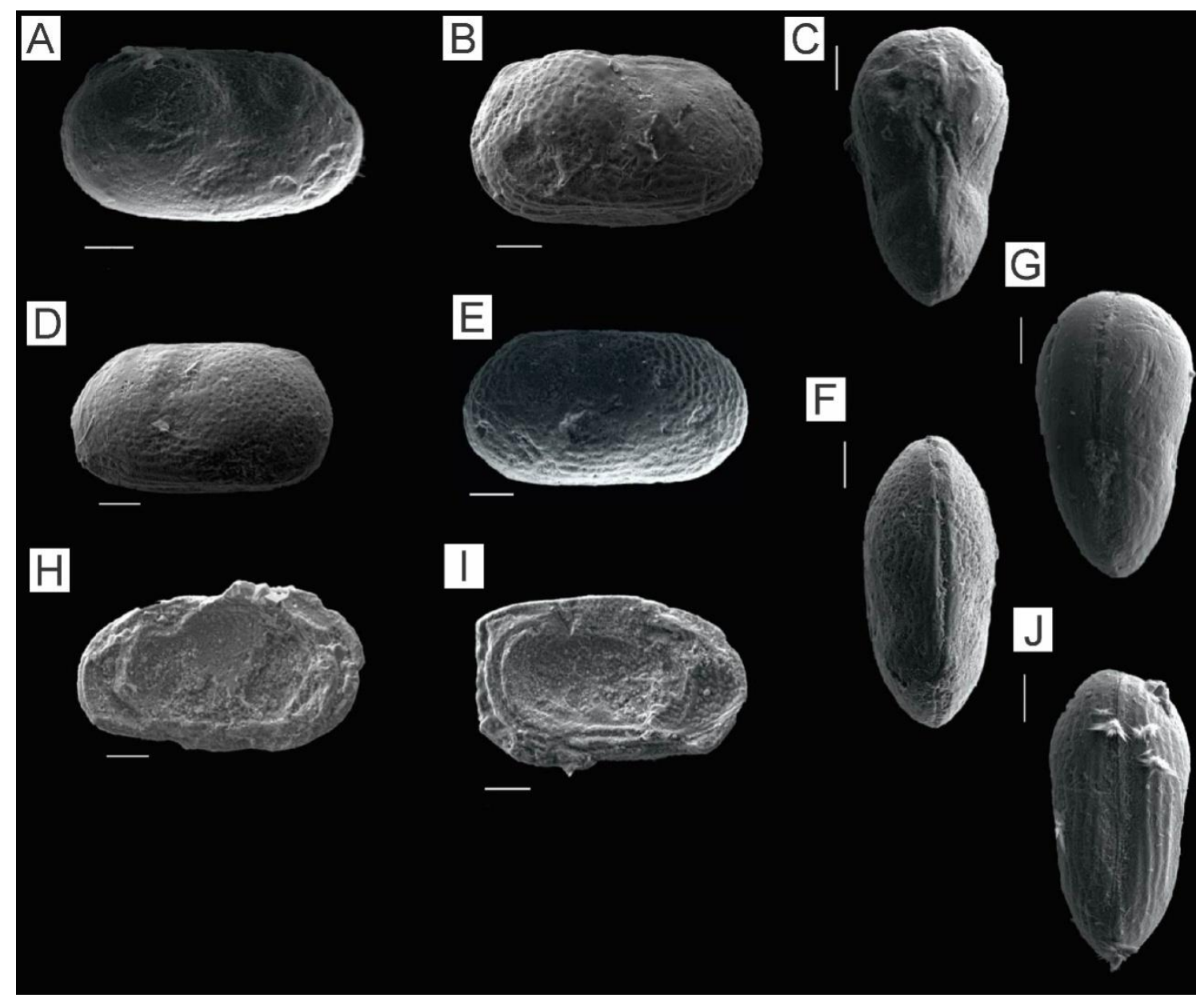

Figure 8: Theriosynoecum. (A): $q$ Right lateral view. (B) $q$ Right lateral view. (C) $q$

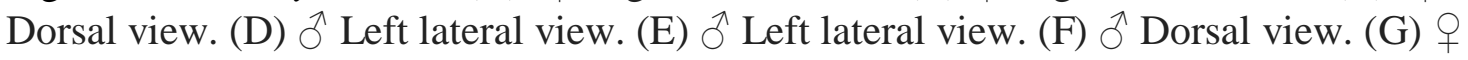
Dorsal view. $(\mathrm{H})$ Internal view. $(\mathrm{F})$ Internal view. Scale: $0,1 \mathrm{~mm}$.

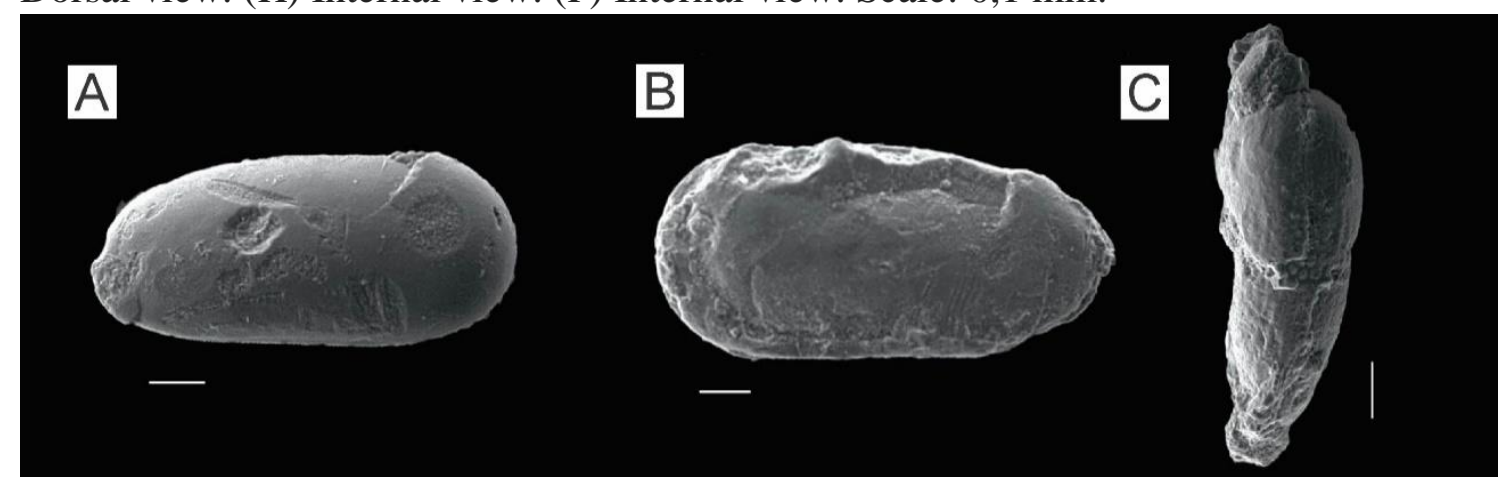

Figure 9: Alicenula. (A) Left lateral view. (B) Right lateral view. (C) Dorsal view. Scale: $0,1 \mathrm{~mm}$.

\section{Sergi Formation}

Sergi Formation is located at the north portion of Mirandiba Basin (Fig. 10A). Its outcrops cover an area of $4 \mathrm{~km}^{2}$. This formation consists of fine- to medium- sandstone, predominating over coarse- and very coarse-grained sandstone. Siltstone layers are observed locally. The sandstone is, in general, moderately sorted, with rounded to subrounded grains and shows pale yellow to white colors. 
The sedimentary structures observed are cross and horizontal stratification. Between different sets is common to observe angular pebbles and rocks fragments.

These rocks are, essentially, composed of quartz and, in smaller proportions, mica and lithic fragments. Five different facies were recognized in Sergi Formation studied outcrops. Sandstone dominated facies are the most common, followed by conglomerate and siltstone dominated.

\section{FACIES DESCRIPTIONS}

\section{Gm: Massive conglomerate}

This facies consists of a matrixsupported conglomerate, containing pebbles of quartz and lithic fragments, which sizes vary from 5 to $15 \mathrm{~cm}$. The matrix is mainly composed of poorly sorted, coarse-grained sandstone (Fig. $10 \mathrm{~B}$ and 10C).

\section{Sm: Massive sandstone}

Fine- to coarse-grained sandstone, well sorted, with subrounded grains (Fig.
10B, E and Fig. 11). Showing, locally, lithic fragments (e.g. gneiss fragments).

\section{Sh: Horizontally stratified sandstone}

Fine- to medium-grained sandstone, well sorted, with subrounded grains. The thickness of the beds vary from $15 \mathrm{~cm}$ to $25 \mathrm{~cm}$ (Fig. 10B, D and Fig. 11).

\section{Sp: Cross-stratified sandstone}

Fine- to very coarse-grained, moderate to well-sorted sandstone. The grains are subrounded and bed geometry is tabular. The most common sedimentary structure is planar crossbedding.

\section{Fl: Fine laminated siltstone}

Fine laminated siltstone, whose beds are approximately $30 \mathrm{~cm}$ thick. They are commonly observed between sandstone dominated facies (Fig. 10F).

Table 3: Facies recognized at Sergi Formation in Mirandiba Basin following the approach of Miall (1977) and Miall (1996).

\begin{tabular}{|c|c|c|}
\hline Facies & Structures & Interpretation \\
\hline $\mathbf{G m}$ & Structureless (massive) & Depositional load as bed sheets or lag channel floor. \\
\hline $\mathbf{S m}$ & Structureless (massive) & Bioturbated sand, or deposition by suspension fallout. \\
\hline $\mathbf{S h}$ & Horizontal stratification & Streams high speed flat bed. \\
\hline $\mathbf{S p}$ & Cross-stratification & Unidirectional migration of subaqueous two- \\
dimensional dunes.
\end{tabular}




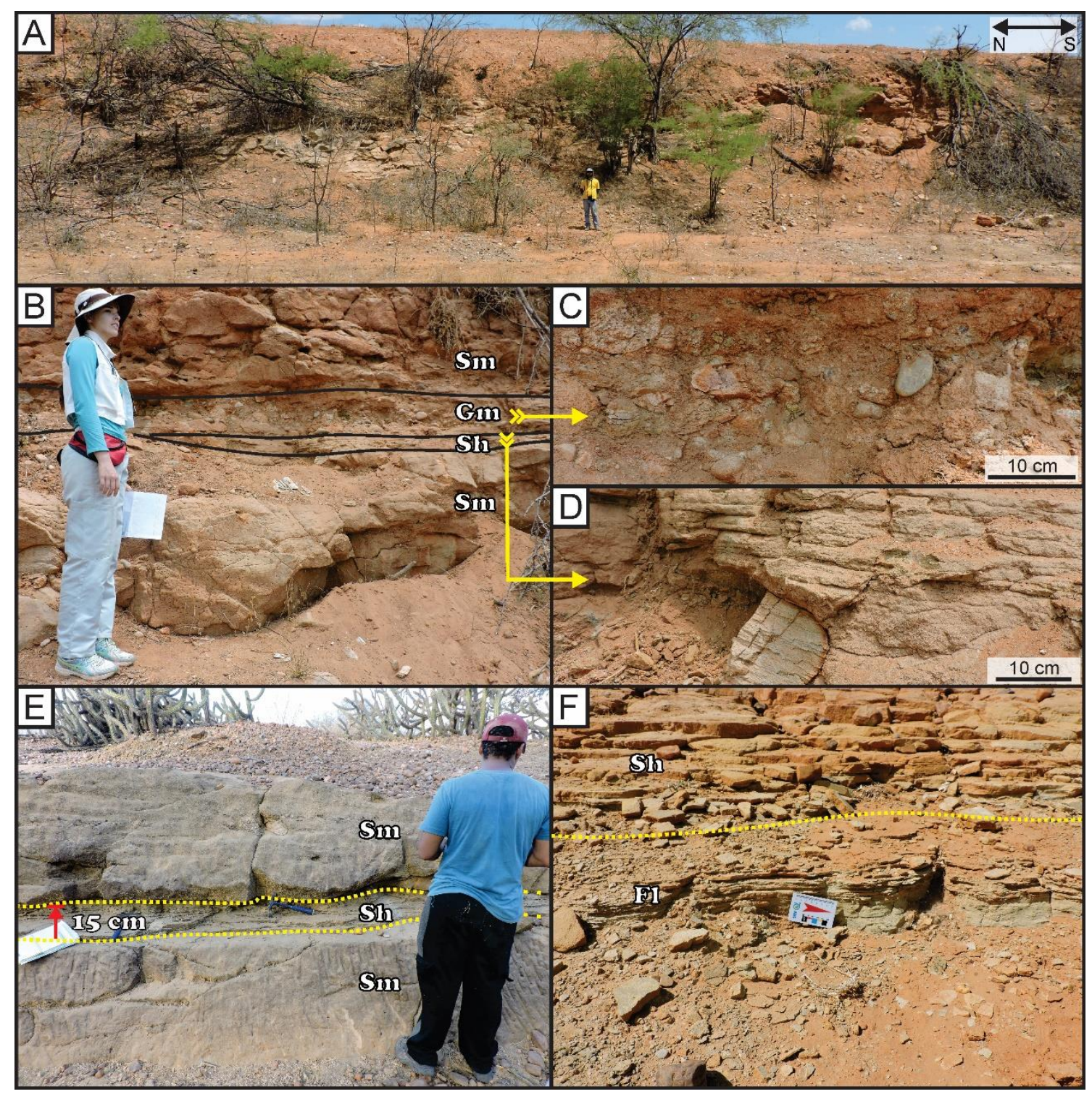

Figure 10: Overview of Sergi Formation outcrop: at a road-cut approximately $30 \mathrm{~m}$ wide and $6 \mathrm{~m}$ high. (B) Lithofacies succession marked by massive sandstone on the base, followed by horizontally stratified sandstone and massive conglomerate. (C) Detail of matrix-supported massive conglomerate (Gm facies), comprising quartz and lithic fragment pebbles. (D) Detail of horizontally stratified sandstone (Sh facies). (E) Horizontally stratified sandstone layer (Sh facies) interbedded by layers of massive sandstone (Sm facies). (F) Contact between fine laminated siltstone and horizontally stratified siltstone. 


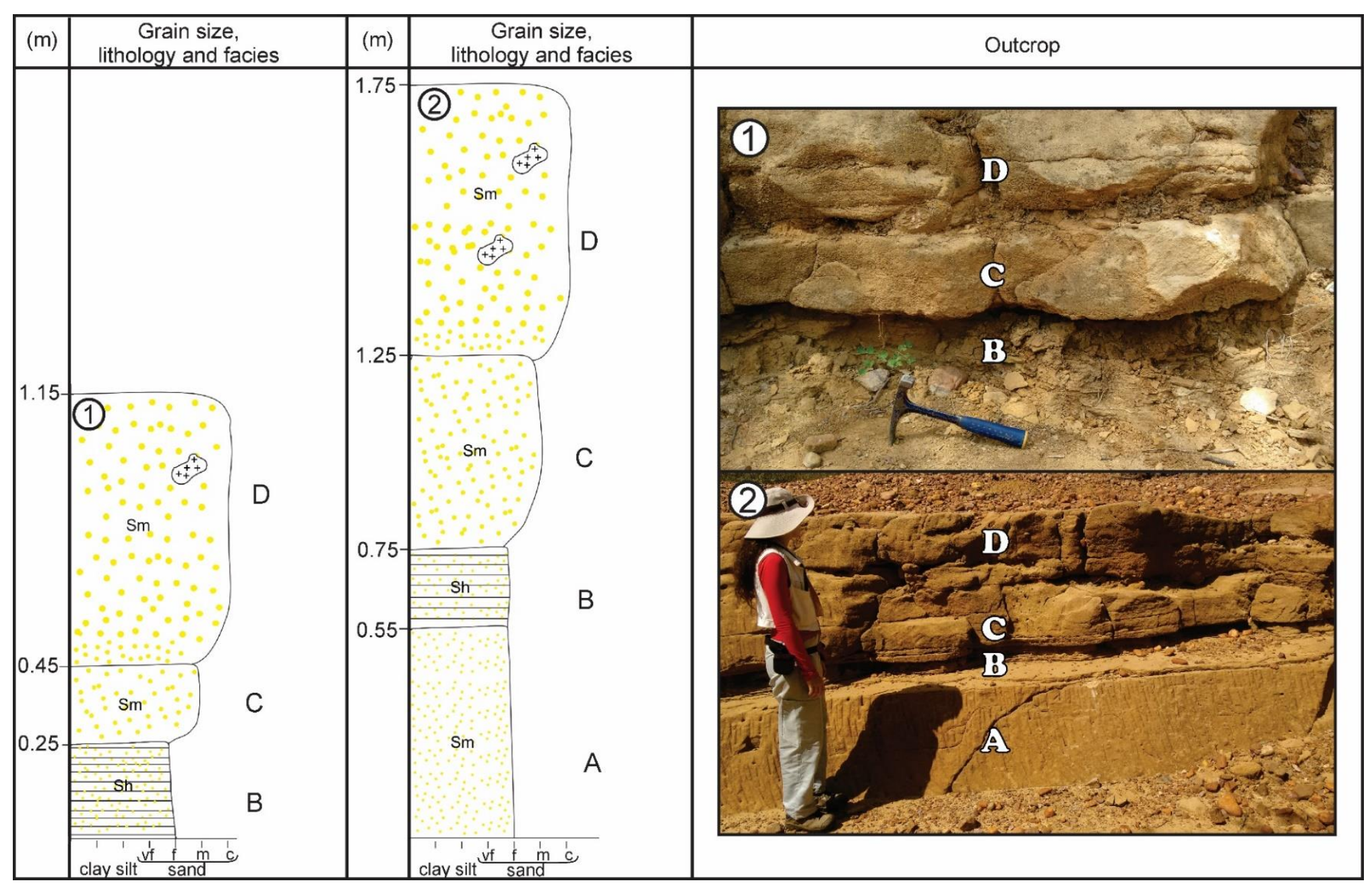

Figure 11: Stratigraphic columns of Sergi Formation outcrops (correlate layers are named with similar letters). Both outcrops show a coarsening upward grain size trend. In (1) is possible to observe the sequence of Sh and Sm facies, represented by B and, C and D, respectively. In (2), is besides those facies, a basal layer " $\mathrm{A}$ " is also observed. 
DISCUSSION AND CONCLUSIONS

Table 4 summarizes facies associations (S1, S2, F1 and S3) for the four formations described in Mirandiba Basin. The facies association S1 comprises the facies $\mathrm{Sm}$, Sh and Sp. It represents part of an architectural element of a river channel with a tabular geometry showing a finning up succession typical of fluvial systems in the Tacaratu and Inajá formations. Composed of facies $\mathrm{Sr}$ and Fm, Facies association $\mathrm{S} 2$ is identified in some outcrops of Inajá Formation. It suggests a shallow marine platform depositional environment; however, this is not enough evidence to support this interpretation. F1 is described in Aliança Formation and it consists of Fm and Sm facies. This association represents a lacustrine environment rectified by biostratigraphic data (Ostracods). The facies association $\mathrm{S} 3$ is composed of facies $\mathrm{Gm}, \mathrm{Sm}, \mathrm{Sh}, \mathrm{Sp}$, and Fl. It is interpreted as a complete river channel
(CH) with overbank/flood deposits of a braided system.

The depositional environments in Mirandiba Basin are mostly continental, but shallow-marine sedimentation could be also interpreted in some outcrops associated with Inajá Formation. Tacaratu, Sergi, and Inajá formations were formed by typical fluvial braided systems, whereas Aliança Formation was generated by a lake deposit. Costa $e t$ al. (2007) argue that Aliança and Sergi's formations are also associated with fluvial and eolian systems, respectively in Jatobá Basin. However, in Mirandiba Basin, we did not find enough evidence to support this interpretation. Probably, it is due to the outcrops poor conservation, small size and shallow depth of the basin.

New researches about Mirandiba Basin are still necessary to improve the knowledge about its genesis, evolution and structural styles.

Table 4: Facies association and depositional environment interpreted in Mirandiba Basin.

\begin{tabular}{|c|c|c|c|c|}
\hline $\begin{array}{c}\text { Facies } \\
\text { Association }\end{array}$ & Facies & $\begin{array}{c}\text { Sedimentary } \\
\text { structures }\end{array}$ & Formation & $\begin{array}{l}\text { Depositional } \\
\text { environment }\end{array}$ \\
\hline \multirow{3}{*}{ S1 } & $\mathrm{Sm}$ & $\begin{array}{l}\text { Structureless } \\
\text { (massive) }\end{array}$ & \multirow{3}{*}{ Tacaratu/Inajá } & \multirow{3}{*}{ Fluvial braided } \\
\hline & Sh & $\begin{array}{l}\text { Horizontal } \\
\text { stratification }\end{array}$ & & \\
\hline & $\mathrm{Sp}$ & Cross-stratification & & \\
\hline \multirow[b]{2}{*}{$\mathbf{S 2}$} & $\mathrm{Sr}$ & Ripples marks & \multirow[b]{2}{*}{ Inajá } & \multirow[b]{2}{*}{$\begin{array}{l}\text { Shallow marine } \\
\text { platform? }\end{array}$} \\
\hline & $\mathrm{Fm}$ & $\begin{array}{l}\text { Structureless } \\
\text { (massive) }\end{array}$ & & \\
\hline \multirow{2}{*}{ F1 } & $\mathrm{Fm}$ & $\begin{array}{l}\text { Structureless } \\
\text { (massive) }\end{array}$ & \multirow{2}{*}{ Aliança } & \multirow{2}{*}{ Lacustrine } \\
\hline & $\mathrm{Sm}$ & $\begin{array}{l}\text { Structureless } \\
\text { (massive) }\end{array}$ & & \\
\hline \multirow{5}{*}{ S3 } & $\mathrm{Gm}$ & $\begin{array}{l}\text { Structureless } \\
\text { (massive) }\end{array}$ & \multirow{5}{*}{ Sergi } & \multirow{5}{*}{ Fluvial braided } \\
\hline & $\mathrm{Sm}$ & $\begin{array}{l}\text { Structureless } \\
\text { (massive) }\end{array}$ & & \\
\hline & $\mathrm{Sh}$ & $\begin{array}{c}\text { Horizontal } \\
\text { stratification }\end{array}$ & & \\
\hline & $\mathrm{Sp}$ & Cross-stratification & & \\
\hline & $\mathrm{Fl}$ & Fine lamination & & \\
\hline
\end{tabular}




\section{Acknowledgments}

The authors thank the Geology Department of Federal University of Pernambuco, the Foundation of Support for Science and Technology of Pernambuco (FACEPE) and the professors and colleagues Sônia Maria Agostinho, Thais Andressa Carrino, Enelise Kátia Piovesan and Wilson Andrade de Freitas for support during the field activities.

\section{REFERENCES}

Aguiar, Robério \& , Liano \& Veríssimo, Silva \&, Leanize \& Oliveira, Teixeira \& Júlio, Manoel \& G Galvão, T \& A C Feitosa, Fernando. 2010. Pesquisa Hidrogeológica em Bacias Sedimentares no Nordeste Brasileiro, 20 p.

Barbosa, O. 1964. Geologia de parte da região do médio São Francisco, Nordeste do Brasil. Petrópolis: PROSPEC, $69 \mathrm{p}$.

Barreto, P.M.C. 1968. Paleozoico da Bacia do Jatobá, Pernambuco. Boletim da Sociedade Brasileira de Geologia, v. 17, n. 1, p. 29-45.

Brasilino, R. G., Miranda, A. W. A., Morais, D. M. F. 2014. Carta Geológica da Folha Mirandiba SC.24-X -A-I. Estado de Pernambuco. Scale 1:100.000. Recife, CPRM, Programa Geologia do Brasil - PGB.

Braun, O.P.G. 1966. Estratigrafia dos sedimentos da parte interior da região Nordeste do Brasil (Bacias do Tucano-Jatobá, Mirandiba e Araripe). Divisão de Geologia e Mineralogia/Departamento

Nacional de Produção Mineral (Boletim $\mathrm{n}^{\circ} 236$ ), 75p.

Chang, H.K., Kowsmann. O., Figueiredo, A.M.F. 1988. New concepts on the development of
East Brazilian marginal basins. Episodes, 11(3):194-202.

Conceição, J.C.J., P. V. Zalán, e S. Wolff. 1988. Mecanismo, evolução e cronologia do Rift SulAtlântico. Boletim de Geociênciencias da Petrobras, 2(2/4):255-265.

Costa, W.D., Santos, M.A.V., Lucas, A.A., Branco, R.L.C., Maranhão, C.M.L. $2006 . \quad$ Estudo Hidrogeológico da Bacia Sedimentar de São José do Belmonte e Diagnóstico das Condições Hidrogeológicas da Bacia Sedimentar de Fátima, Visando a Instalação de Sensores Telemétricos. Projeto Proágua Semiárido. Secretaria de Ciência, Tecnologia e Meio Ambiente de Pernambuco. p. 113-145. Leite, J. F.; Pires S. DE T. M.; Rocha, D. E. G. A. da. 2001. Estudo Hidrogeológico da Bacia do JatobáPE. Série Hidrogeologia. Estudos e Projetos. v. 7. 55p.

Leite, J.F., Pires, S.T.M., Rocha, D.E.G.A. 2000. Estudo Hidrogeológico da Bacia de Fátima-PE. Relatório Interno CPRM, 99p.

Matos, R.M.D. de. 1992. The Northeast Brasilian Rift System: Tectonics, 11(4): 766-791.

Matos, R.M.D. 1999. History of the northeast Brazilian rift system: kinematic implications for the break-up between Brazil and West Africa. In The Oil and Gas Habitats of the South Atlantic (Eds. N.R. Cameron, R.H. Bate and V.S. Clure), Geological Society of London, Special Publication, 153, 55-73.

Medeiros, V.C. 2004. Evolução geodinâmica e condicionamento estrutural dos terrenos Piancó-Alto Brígida e Alto Pajeú, Domínio da Zona Transversal, NE do Brasil. 
PhD Thesis. Universidade Federal do Rio Grande do Norte, 200 p.

Miall, A.D. 1977. A review of the braided-rivers depositional environment.Earth Science Reviews, 13(1):1-62.

Miall, A.D. 1996. The geology of fluvial deposits: sedimentary facies, basin analysis and petroleum geology. Berlin, Springer, $582 \mathrm{p}$.

Pereira, P.A.; Almeida, J.A.C.; Barreto, A.M.F. 2012. Paleoecologia dos bivalves e braquiopodes da Formação Inajá (Devoniano), Bacia do Jatobá (PE), Brasil. Estudos Geológicos, v. 22, n. 1, p. 37-53.

Ponte, F.C.1971. Evolução paleogeológica do Brasil oriental e da África ocidental. Salvador. Bahia. PETROBRAS SEPES SETUP/BA, $4^{\circ}$ Curso de Projetos Especiais em Geologia - (CPEG IV), $73 \mathrm{p}$.

Ponte, F.C. \& Ponte Filho, F.C. 1996a. Estrutura geológica e evolução tectônica da Bacia do Araripe. Recife: Departamento Nacional da Produção Mineral, $4^{\circ}$ e $10^{\circ}$ Distritos Regionais, Delegacias do Ministério das Minas e Energia em Pernambuco e Ceará, 68 p.

Ponte, F. C., Hashimoto, A. T., Dino, R. 1991. Geologia das bacias sedimentares mesozoicas do interior do Nordeste do Brasil. PETROBRAS/CENPES/DIVEX/ SEBIPE.

\section{Laís Cristina Leite Pereira et al.}

Rocha, D. E. G. A., Leite, J. F. 1999. Estudo Hidrogeológico da Bacia do Jatobá - Geologia. Recife. CPRM. p. 20.

Silva, G. M., Piosevan, E. K, Lima Filho, M. F. 2017. Ostracodes NãoMarinhos da Formação Aliança na Bacia de Mirandiba, Nordeste Do Brasil. XXVII Simpósio De Geologia Do Nordeste, Paraíba.

Silva Jr., J. M. F. 1997. Um Regime Rúptil, Pós-Siluro-Devoniano no Domínio da Zona Transversal,

Província Borborema-Nordeste do Brasil. Master Thesis. Universidade Federal de Ouro Preto.

Soares, P.C., Landim, P.M.B., Fúlfaro, V.J. 1978. Tectonic cycles and sedimentary sequences in the Brazilian intracratonic basins. Geol. Soc. Am. Bull, 89:181-191.

Vauchez, A., Neves, S., Caby, R., Corsini, M., Egydio-Silva, M., Arthaud, M., Amaro, V. 1995.The Borboreme shear zones system, NE Brazil. Journal of South American Earth Sciences, 8(3-4): 247-266. 